Review

\title{
Managing agricultural phosphorus to minimize water quality impacts
}

Andrew Sharpley

University of Arkansas/Division of Agriculture University of Arkansas System - Dept. of Crop, Soil and Environmental Sciences, 115 Plant Sciences Building - 72701 - Fayetteville, AR - USA.

*Corresponding author <Sharpley@uark.edu>

Edited by: Paulo Sérgio Pavinato

Received March 10, 2015

Accepted September 02, 2015

\begin{abstract}
Eutrophication of surface waters remains a major use-impairment in many countries, which, in fresh waters, is accelerated by phosphorus $(\mathrm{P})$ inputs from both point (e.g., municipal waste water treatment plants) and nonpoint sources (e.g., urban and agricultural runoff). As point sources tend to be easier to identify and control, greater attention has recently focused on reducing nonpoint sources of $\mathrm{P}$. In Brazil, agricultural productivity has increased tremendously over the last decade as a consequence, to a large extent, of increases in the use of fertilizer and improved land management. For instance, adoption of the " $4 R$ " approach (i.e., right rate, right time, right source, and right placement of $P$ ) to fertilizer management can decrease $P$ runoff. Additionally, practices that lessen the risk of runoff and erosion, such as reduced tillage and cover crops will also lessen $P$ runoff. Despite these measures $P$ can still be released from soil and fluvial sediment stores as a result of the prior 10 to 20 years' management. These legacy sources can mask the water quality benefits of present-day conservation efforts. Future remedial efforts should focus on developing risk assessment indices and nonpoint source models to identify and target conservation measures and to estimate their relative effectiveness. New fertilizer formulations may more closely tailor the timing of nutrient release to plant needs and potentially decrease P runoff. Even so, it must be remembered that appropriate and timely inputs of fertilizers are needed to maintain agricultural productivity and in some cases, financial support might also be required to help offset the costs of expensive conservation measures.

Keywords: fertilizer management, conservation practices, runoff, erosion, eutrophication
\end{abstract}

\section{Introduction}

The accelerated eutrophication of freshwaters and to a lesser extent some coastal waters is primarily driven by phosphorus $(\mathrm{P})$ inputs. While efforts to identify and limit point source inputs of $\mathrm{P}$ to surface waters have seen some success, nonpoint sources have remained elusive and more difficult to identify, quantify, target, and remediate. Thus, attention has focused more on nonpoint source reduction, particularly the role of agriculture. This attention has increased over the last 10 years due to the fact that impaired water quality has not seen as great an improvement as expected after the adoption of conservation practices.

The increased use of fertilizer and manures has contributed to a steady increase in corn (Zea mays) and soybean (Glycine max) yields in Brazil (USDA, 2015a and 2015b) (Figure 1A). In many cases, record corn and soybean yields have been achieved since 2012 and are expected to surpass U.S. soybean production for the first time in 2015 (USDA, 2015c).

Along with increased crop production, there have been tremendous changes in agricultural production systems in most developed countries, with crop and animal operations evolving into spatially separate production systems. In Brazil, there has been a 4.5-fold increase in fertilizer P use on agricultural lands since 1975 (Figure 1A). Up to now there has been a $128 \%$ increase in the amount of $\mathrm{P}$ produced in manure by beef, $13 \%$ increase for swine, and $88 \%$ increase for poultry (Figure 1B; IBGE, 2014).

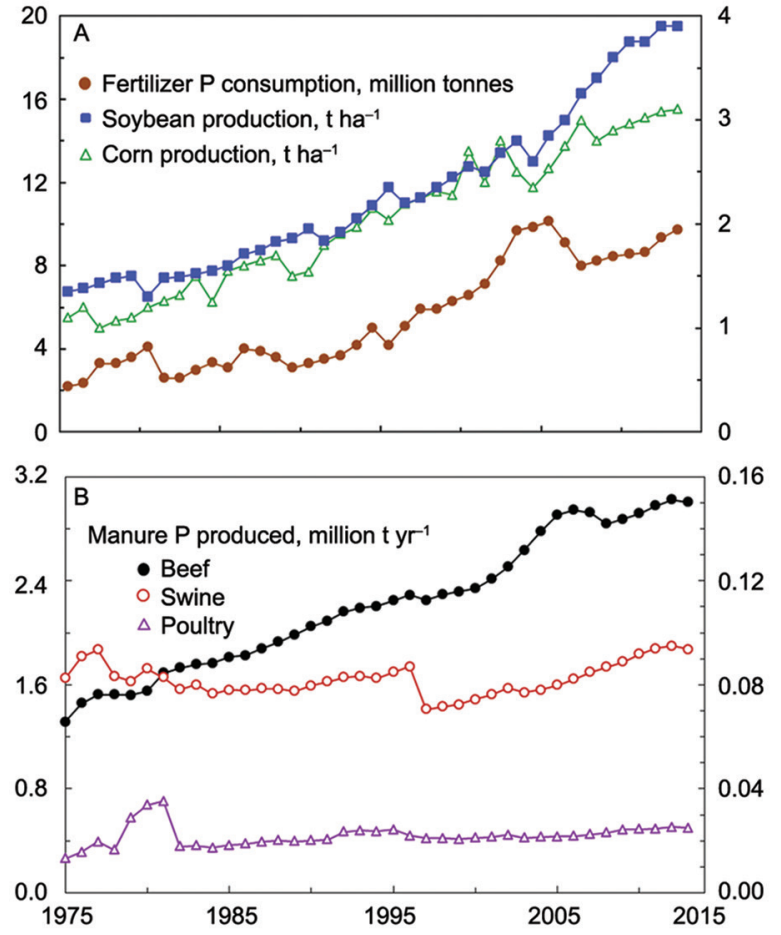

Figure 1 - Fertilizer P consumption and soybean and corn production between 1975 and 2014 (upper graph; A) and manure P produced by livestock over the same period P (lower graph; B) in Brazil. Data from the Brazilian Institute of Geography and Statistics, 2014 and the U.S. Department of Economic Research Service, 2013. 
The fact that Brazil has almost twice the available water resources than the next ranked country, Russia, and over 2.5 times more than the U.S., highlights the tremendous potental for the continued growth of Brazilian agriculture and its productivity (Figure 2; Food and Agriculture Organization, 2015). Thus, the wise use of water and nutrients now will minimize the risk of water quality degradation issues that the U.S. and China, for instance, now face. This sustainable or conservationist approach to nutrient and agricultural management will also, importantly, limit external pressures that would be levelled at agricutlural stakeholders to mitigate degradation. This has certainly become an issue that is hotly and fractiously debated worldwide, where $\mathrm{P}$ impairment of surface waters persists, such as in Asia (Dai et al., 2011; Li et al., 2015; Novotny et al., 2010; Sun et al., 2012), Europe (Hilton et al., 2006; Withers and Jarvie, 2008), and U.S. (Dubrovsky et al., 2010; National Research Council, 2008).

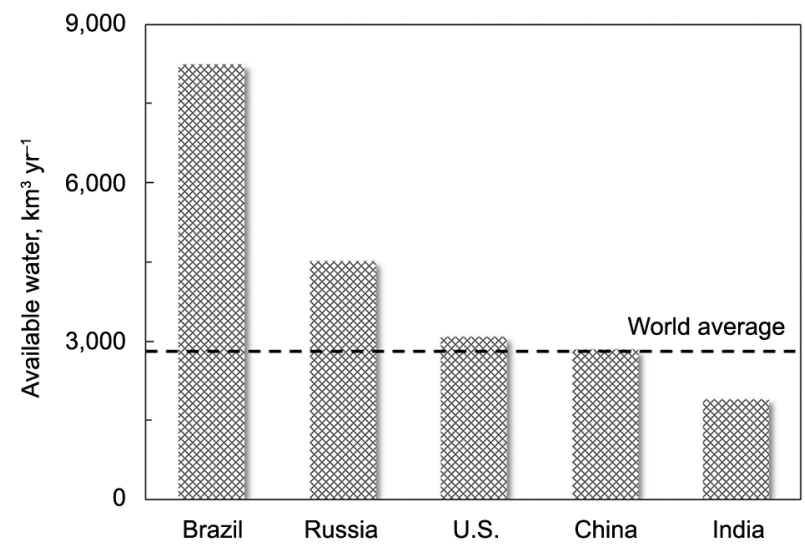

Figure 2 - Water resource availability for several countries, showing that Brazil has twice the volume of water resources than any other country.
While grazing-based beef production is an extensive system, where manure is deposited over grazed pastures, confined or housed swine and poultry are intensive systems, producing large amounts of manure in localized areas. The large increase in size and number of animal production systems creates localized surpluses of P-rich manure due to the major input of nutrients in animal feed from grain-producing areas. This accumulation leads to an overall increase in the risk of $\mathrm{P}$ runoff. Management of fertilizer to maximize grain and livestock production, while minimizing environmental impacts, has evolved into nutrient and conservation management strategies (Figure 3). Strategically targeting these management strategies to critical areas of the landscape and to regions of the country, where there is the potential for accumulation of nutrients, is key to minimizing the impact of agricultural P-related water quality issues.

This paper reviews the management of $\mathrm{P}$ applications in mineral and manure forms to agricultural land in Brazil, in the context of examples and lessons learnt from other countries. Brazilian agriculture has tremendous potential for growth, along with an opportunity to continue this growth in an environmentally sustainable manner. As several land management terms used in this review might differ slightly between the Brazil and the U.S., they are defined herein for clarification. No-till (also called zero tillage or direct drilling) is a way of growing crops from year to year without disturbing the soil through tillage (i.e., plowing). Minimum tillage is the least amount possible of cultivation or soil disturbance incurred to prepare a suitable seedbed. This means that physically, the soil is not inverted, which is usually desirable, as intensive tillage tends to break down soil structure. Finally, conventional tillage is a tillage system using cultivation as the major means of seedbed preparation and weed control.

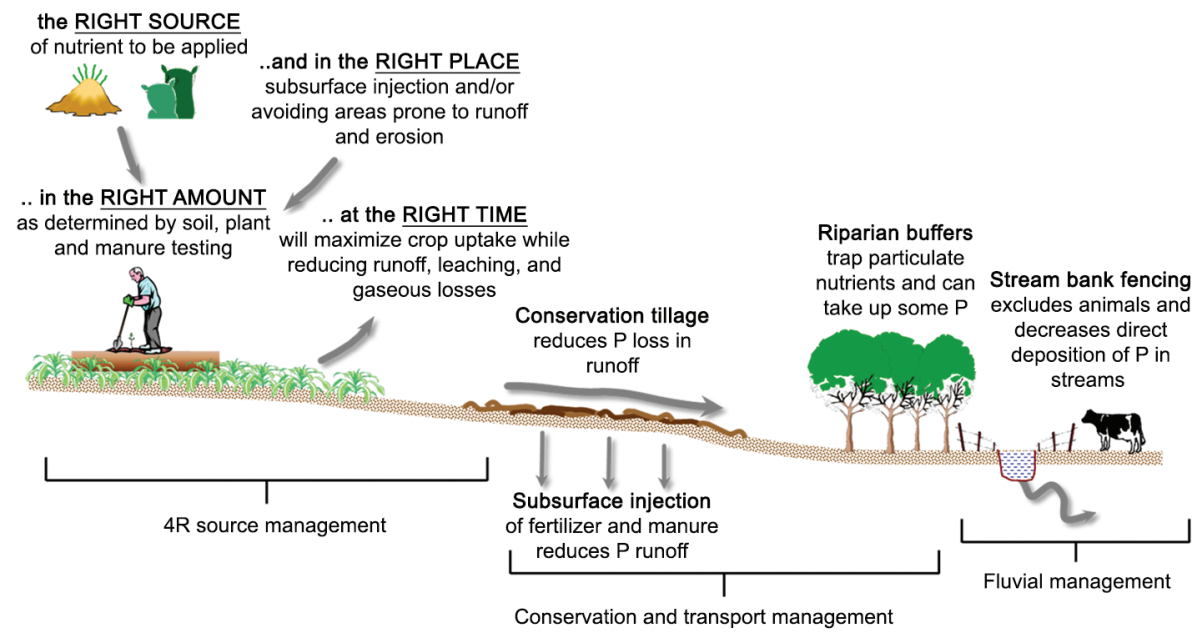

Figure 3 - "4R" nutrient source management and conservation management of $\mathrm{P}$ in agricultural production systems. 


\section{Nutrient management}

Careful nutrient management planning on a fieldby-field and farm basis is a major component of any remedial action plan to minimize the risk of nutrient loss from agricultural land. This basically follows the "4R" nutrient management approach advocated by the IFA (2009) and IPNI (2014), which is adding P at the $\mathbf{R}$ ight rate to match crop needs, in the Right source, at the Right time, and in the Right place (Figure 3).

\section{The Right Rate}

Fertilizer P rates are usually established by crop need and modified by the amount already in the soil, as determined by established soil $\mathrm{P}$ test methods. In the case of commercial P fertilizer, applications can be tailored to match crop needs and minimize excessive soil $\mathrm{P}$ accumulation, because of the economic incentive of avoiding applying too much costly fertilizers.

\section{The Right Source}

Fertilizer nutrients can be formulated to match crop needs; however, manures have more $\mathrm{P}$ than $\mathrm{N}$ compared to crop needs. For instance, the ratio of $\mathrm{N}: \mathrm{P}$ in manure (2 to $4: 1)$ is three to four times lower than that taken up by major grain and hay crops (8:1). As a result, applications of manure to meet crop $\mathrm{N}$ needs, apply three to four times more $\mathrm{P}$ than annual crop needs. Repeatedly applying manure at rates to provide sufficient $N$, will increase soil $P$ levels and the risk of $\mathrm{P}$ runoff. On the other hand, application of manure to meet crop $\mathrm{P}$ needs will apply insufficient $\mathrm{N}$, putting an economic burden on farmers to purchase costly mineral $\mathrm{N}$.

To address this, there needs to be a greater exchange and coordination of information among researchers, farm advisors, and fertilizer consultants, to increase the awareness and availability of different fertilizer formulations. Awareness of the range of nutrient formulations commercially available to farmers can help farmers tailor $\mathrm{N}, \mathrm{P}$, and $\mathrm{K}$ additions to crop needs and to what is already in the soil and available for plant uptake.

\section{The Right Time}

Many studies show the loss of $\mathrm{P}$ in runoff relates directly to the timing of applied P (Dampney et al., 2000; Sharpley et al., 2007; Sims and Kleinman, 2005). Avoiding applications within a few days of expected rainfall can minimize runoff losses due to the sorption of added $\mathrm{P}$ with soil. Several studies show, for example, reductions in $\mathrm{N}$ and $\mathrm{P}$ losses with an increase in the length of time between manure application and surface runoff (Djodjic et al., 2000; Edwards and Daniel, 1993; Sharpley, 1997; Westerman et al., 1983). These reductions can be attributed to the reaction generated when $\mathrm{P}$ is added to the soil and dilution of applied $\mathrm{P}$ by infiltrating water from rainfall that did not cause surface runoff. However, timing the application of $\mathrm{P}$ to avoid times of the year when the risk of rain-induced runoff is greatest, must be tempered with providing the nutrients at the time of most active plant uptake.

\section{The Right Place}

Because of the relative immobility of $\mathrm{P}$ in soil, placement of $\mathrm{P}$ fertilizer is generally more critical for plant availability than is the case for $\mathrm{N}$ fertilizer. The incorporation of manure into the soil profile, either by tillage or subsurface placement, reduces the potential for P runoff. For example, Mueller et al. (1984) showed incorporation of dairy manure by chisel plowing reduced total $\mathrm{P}$ loss in runoff from corn 20-fold, compared to notill areas receiving surface applications.

\section{Conservation and transport management}

Transport management refers to efforts to control the movement of $\mathrm{P}$ from soils to sensitive locations such as bodies of fresh water. Phosphorus loss via surface runoff and erosion may be reduced by conservation tillage and crop residue management, buffer strips, riparian zones, terracing, contour tillage, cover crops, and impoundments or ponds. These practices tend to reduce rainfall impact on the soil surface, reduce runoff volume and velocity, and increase soil resistance to erosion. However, none of these measures should be relied on as the sole or primary practice to reduce P runoff.

Adoption of conservation measures has been enocuraged in many areas. In the U.S. for example, Gulf of Mexico hypoxia has led to a large scale initiative to implement conservation practices in the contributing Mississippi River Basin in the U.S. (Dale et al., 2010). The Mississippi River Basin drains $41 \%$ of the U.S. (or 1,245,000 miles ${ }^{2}$ ). Thus, spatially expansive sources of $\mathrm{P}$ and the relative contributions of municipalities, industries, and agriculture, create system complexities that should not limit action by any one entity. Recent model estimates (USGS-SPARROW; Alexander et al., 2008) suggest that up to $85 \%$ of the $\mathrm{P}$ and $\mathrm{N}$ entering the Gulf of Mexico originate from agriculture. Government agencies charged with implementing and checking compliance with conservation programs used these model estimates to prioritize allocation of conservation cost-share funding under the 2009 Healthy Mississippi River Basin Initiative (\$320 million over 5 years) to 41 of the top contributing sub-watersheds in 13 states along the Mississippi River corridor (USDA, 2009). One unique aspect of this program has been the provision of financial incentives to farmers to conduct edge-of-field monitoring to quantify the effectiveness of conservation practices to reduce nutrient runoff. These initiatives have been very successful in getting conservation systems implemented on a large acreage of agricultural lands to help farmers address water quality concerns. However, a transparent framework is needed to document and verify on-the-ground conservation practices to ensure farmers are credited with accurate reductions. 


\section{Legacies of past management}

Past land use or land management activities can lead to a long-term legacy of $\mathrm{P}$ in watersheds (Figure 4). This legacy of $P$ refers to $P$ stored in surface soils, ditches, riparian zones, wetlands, stream, and lake sediments from prior land and nutrient management (Meals et al., 2010; Sharpley et al., 2013). The stored $\mathrm{P}$ can be subsequently re-released as the P storage capacity gradually becomes saturated, or after a change in land use, or land management. Lag times associated with release of $\mathrm{P}$ from the $\mathrm{P}$ legacy stores may help explain difficulties in detecting water quality improvements at a watershed scale. For example, where soil $\mathrm{P}$ test levels have risen to more than 10 times crop sufficiency levels, it can take a decade or more to 'draw down' soil $\mathrm{P}$ reserves to levels where dissolved $\mathrm{P}$ in runoff is substantially reduced (Cox et al., 1981; Shulte et al., 2010). However, by developing watershed-scale monitoring that identifies local-scale improvements and associated time lags in water quality as they occur, watershed planners can start to better understand and plan mitigation strategies.

The richly documented history of water quality in the Lake Erie Watershed, outbreaks of harmful algal blooms, and land management in the Watershed over the last 50 years, provides an excellent example of how well-meaning conservation strategies can result in intended and unintended consequences on the fate of $\mathrm{P}$ and transport. Steady declines in $\mathrm{P}$ inputs from predominantly agricultural watersheds were measured between 1980 and 1995 with the adoption of conservationist practices, such as nutrient management planning that reduced fertilizer and manure ap- plications to corn and soybeans and a transition to notill cropping.

However, simply implementing conservation practices may not always provide the desired outcomes. For example, despite widespread adoption of conservation in the Lake Erie Watershed, increased losses of $\mathrm{P}$ in agricultural runoff over the last decade, have resulted from complex, dynamic, but predictable factors. These include the accumulation of $\mathrm{P}$ at the soil surface, a fall in the application of fertilizer, continued surface broadcasting of $\mathrm{P}$, a focus on implementing conservation practices that reduce erosion and $\mathrm{P}$ particulate loss, a rapid rise in tile drainage $\mathrm{fu}-$ elled by higher grain prices, and release and remobilization of fluvial P. For instance, there are now more fields with tile drainage that connect to ditches and streams, contributing source areas of the legacy of $\mathrm{P}$ to Lake Erie. The combination of these factors created a "perfect P loss situation," which, along with more intense summer rains, increased $\mathrm{P}$ inputs to Lake Erie to record levels in 2010, culminating in the 2014 toxic bloom and water crisis in Toledo, OH. In the year that followed, there were at least 25 theories proposed as to what may have contributed to the harmful and nuisance algal blooms (Smith et al., 2015). However, scientifically valid remedial strategies were not likely to be readily adopted by farmers due to several logistical, practical, and cost limitations (Daloğlu et al., 2012; Michalak et al., 2013; Sharpley et al., 2012). Clearly, the research community needs to work closely with the farming community to generate innovative support, stewardship, and reward programs that will empower change.

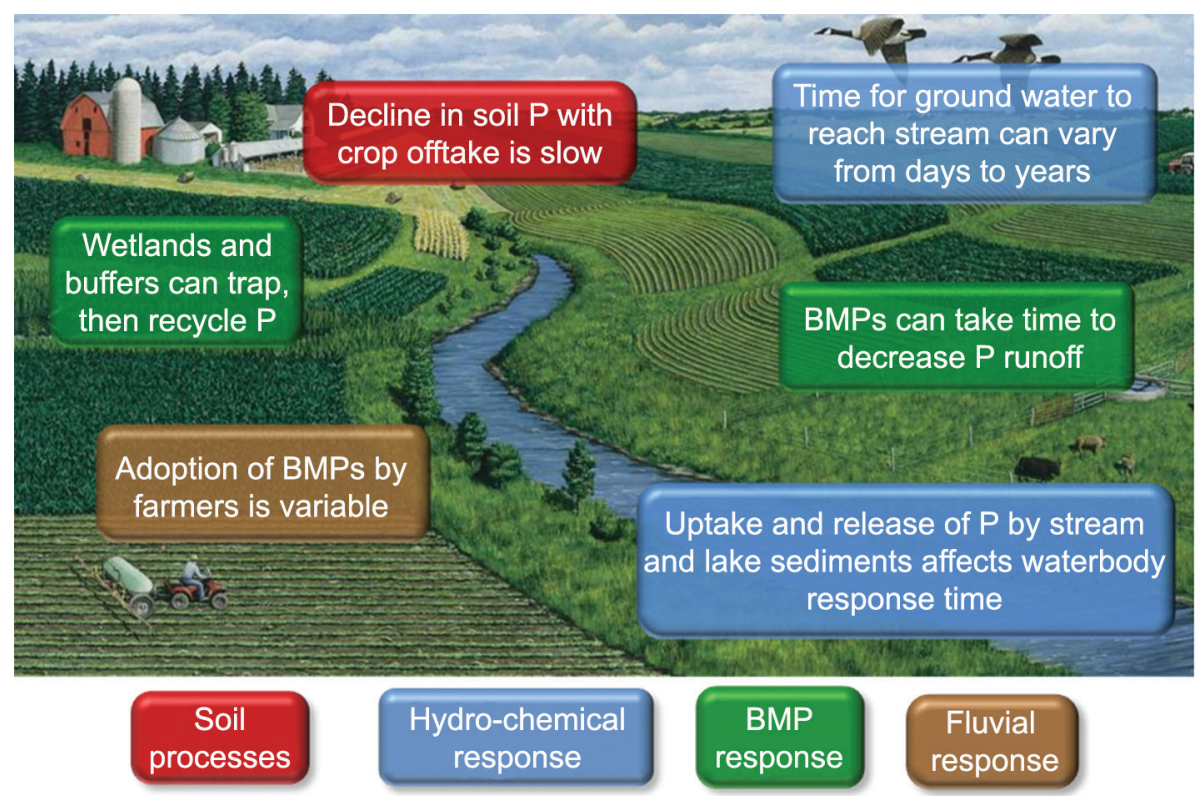

Figure 4 - Conceptual representation of natural, managed, soil, and Best Management Practices processes influencing the lag time for system response. 
Future challenges for fertilizer management and water quality

\section{Fertilizer-P use efficiency}

Several reviews and status perspectives of global cycling of $\mathrm{P}$, have acknowledged that the biogeochemical $\mathrm{P}$ cycle has failed on a global, national, regional, and farm scale (Sharpley and Jarvie, 2012; Jarvie et al., 2013; Haygarth et al., 2014). The failed P cycle in mining, fertilizer production, and land application of $\mathrm{P}$ in livestock manure, food waste, and human waste is the underlying problem since it limits sustainable $\mathrm{P}$ use. Contributing to a solution is the need to Realign the inputs of $\mathrm{P}$, Reuse $P$ from manures and residuals (Bonvin et al., 2015; Stutter, 2015), Recover P from waste, Redefine systems, and Reduce P losses. This was defined as the $5 \mathrm{R}^{\prime} \mathrm{s}$ of $\mathrm{P}$ management stewardship by Schoumans et al., (2015), which is an update of the " $4 \mathrm{R}$ " nutrient management stewardship, specifically formulated to address the failed $\mathrm{P}$ cycle, which is the root cause of $\mathrm{P}$ related use-impairments of water from accelerated eutrophication. Thus, increasing the efficiency of $\mathrm{P}$ use within agricultural systems, which include intensively concentrated and spatially separated livestock and arable operations is critical to resolving the current unsustainable $\mathrm{P}$ cycle.

The development and use of slow release fertilizers, mixing mineral and organic $\mathrm{P}$ fertilizers, fertigation, and the advancement of biofertilizers (i.e., inoculation of seed with effective $\mathrm{P}$ solubilizing microorganisms), are important research opportunities that may hold promise. The development of fertigation and biofertilizers have been reviewed elsewhere (Bauder et al., 2014; Cruz et al., 2012; Stewart and Gordon, 2008; Yara, 2014). The main points relevant to the present discussion of environmental stewardship are that as the costs of these products decrease, they will provide farmers new and real opportunities to closely tailor fertilizer nutrient applications to crop needs. The use of a reactive phosphate rock, such as North Carolina Rock Phosphate, has been shown to be another way to sustain crop productivity on certain soil types, while at the same time, minimizing $\mathrm{P}$ runoff (Shigaki et al., 2006, 2011).

\section{Defining $P$ transport pathways}

When $\mathrm{P}$ is land applied in the form of either mineral or organic fertilizer, surface and subsurface hydrological pathways transport $\mathrm{P}$ from the land surface, where it is a valuable resource used to achieve and maintain optimum plant yields, to receiving waters where it can be a major contributor of water-use impairment. Hydrological pathways along which $\mathrm{P}$ is transported are often complex and tortuous, involving multiple contributions from surface and subsurface transfers (Gburek and Sharpley, 1998; Heathwaite and Dils, 2000). The complexity of subsurface drainage and difficulties in deconvoluting flow pathways were identified as key gaps in our understanding of $\mathrm{P}$ transport and fate, particularly in groundwater-dominated watersheds.
It is clear that hydrological pathways along which $\mathrm{P}$ is transmitted, do not simply transport $\mathrm{P}$ conservatively, but act as a series of reactive conduits, mediating $\mathrm{P}$ flux transformations through retention and recycling of $\mathrm{P}$, on a range of timescales from years to centuries (Jarvie et al., 2014; Sharpley et al., 2013). While inherent hydrological pathways are to a large extent a function of site topography and geology, they must be quantified to reliably estimate the timing and extent of $\mathrm{P}$ loss reductions that can be achieved with land management changes.

Modeling nonpoint $\mathbf{P}$ transport on a watershed scale Nonpoint source models represent mathematical descriptions, ranging from simple (risk assessment indices) to more complex scientific understanding about chemical, physical, and biological processes, which determine P movements within a watershed. Use of nonpoint source models provides a method of simulating the risk of $\mathrm{P}$ loss or estimating the relative effects of change in climate, land use, and land management practices on sediment and nutrient loss. Models have strong appeal to policymakers and managers, because models provide answers much more quickly than can be obtained from field measurements and monitoring. However, this appeal can bring with it false confidence and misconceptions about the reliability of the predictions (Boesch et al., 2001).

Thus, it is important that model developers clearly define what the model is useful for and what it is not designed to do. Likewise, model users must decide what they want to accomplish with a model. For example, one must consider the scale (field, watershed, or basin), time (flow event, annual, or multi-year), and level of accuracy (0.1 or $10 \mathrm{~kg} \mathrm{ha}^{-1} \mathrm{yr}^{-1}$ ) that needs to be simulated, as well as the amount and quality of data available. The predictive uncertainty of models can result from imperfect mathematial representations of the real world, numeric approximations in equations, inaccurate model input data, and uncertainties in input data (Harmel et al., 2006). Nevertheless, because models play an important role in scientific studies and policy decision-making, every effort must be made to obtain reasonable estimates of model uncertainties and make the estimates clear to all those using the model output. In other words, we should not be using models to predict the effect of changing land management on the magnitude of $\mathrm{P}$ loss to an accuracy of say $0.1 \mathrm{~kg} \mathrm{P} \mathrm{ha-1} \mathrm{yr}^{-1}$, when model uncertainty can be as much as $\pm 50 \%$.

\section{Implementing appropriate conservatoin practices}

While there are many Best Management (or conservation) Practices (BMPs) that can be implemented over a wide range of scales to minimize the loss of $\mathrm{P}$ from agriculture to surface and ground waters (Figure 4), cost-benefit estimates are needed for more widespread adoption. If a farmer does not receive financial support to implement a conservation practice, then it is not likely to be adopted voluntarily unless it either makes or saves the farmer money. 
For real and lasting changes to occur in agricultural systems, balancing production and environmental stewardship constraints, there needs to be greater consideration of socioeconomic drivers of what, how, and why some conservation practices are adopted and others are not (Kleinman et al., 2015). There should be greater emphasis on education, outreach, and consumer-driven programs rather than assuming that farmers will absorb the total costs associated with implementing remedial practices. Bearing this in mind, except for decreasing off-farm import of $\mathrm{P}$ and increasing on-farm P-use efficiency, conservation practices are thus only a temporary measure for minimizing $\mathrm{P}$ loss and receiving water impacts.

There needs to be a discussion of how regional, as well as national agricultural infrastructures, can control $\mathrm{P}$ inputs to farming systems and assess large-scale nutrient balances. However, it must be kept in mind that some P loss cannot be avoided, such as during large storm events. Thus, there needs to be an emphasis on quantifying background or baseline losses of $\mathrm{P}$, to better define what reductions or targeted P loss goals might be achievable. For example, while pristine water conditions might be most desirable, watersheds are naturally leaky systems and some loss of $\mathrm{P}$ will have to be accepted where anthropogenic inputs of $\mathrm{P}$ to a watershd have occurred (Haygarth et al., 2014).

\section{Conclusions}

The failed cycling of $\mathrm{P}$ in mining, fertilizer production, and land application as an essential plant nutrient to the recovery and reuse of $\mathrm{P}$ in human waste, livestock manure, and food waste is the underlying problem. This limits sustainable $\mathrm{P}$ use and is the root cause of $\mathrm{P}$ related use-impairments of water from accelerated eutrophication. Thus, increasing the efficiency of $\mathrm{P}$ use within agricultural systems that include intensively concentrated and spatially separated livestock and arable operations, is a critical component in resolving the failed $\mathrm{P}$ cycle situation (Haygarth et al., 2014).

Pressures placed on farmers to maximize yields in response to increasing demand for cheap food, feed, and fuel due to an increasing global population that is becoming more affluent are on the increase. To a large extent this has been made possible by the development and use of fertilizer. At the same time, increased pressures are being placed on farmers to be environmental stewards. However, despite a long history of soil and water $\mathrm{P}$ research, management questions still exist and water-use impairment continues as a result of $\mathrm{P}$ enrichment of soil-water systems. Thus, we need to accept that current research knowledge has to be translated and transferred better to farmers, while at the same time realizing that farm management decisions are largely driven by competitive economics.

The recent involvement of farmers in on-farm environmental stewardship programs and more site monitoring of edge-of-field $\mathrm{P}$ losses, will provide documen- tation on how successful they have been at conserving on-farm P. While many conservation programs have led to more widespread adoption of conservation practices aimed at reducing $\mathrm{P}$ loss, on-farm research and monitoring will help farmers document and receive credit for their efforts. This is particularly important to the voluntary adoption of conservation practices, which tend to have less tracking by and accountability to Federal agencies, but are, nevertheless, as effective as regulated practices.

\section{References}

Alexander, R.B.; Smith, R.A.; Schwarz, G.E.; Boyer, E.W.; Nolan, J.V.; Brakebill, J.W. 2008. Differences in phosphorus and nitrogen delivery to the Gulf of Mexico from the Mississippi River Basin. Environmental Science \& Technology 42: 822-830.

Bauder, T.A.; Waskom, R.M.; Andales, A. 2014. Nitrogen and Irrigation Management. Colorado State University Extension, Ft. Collins, CO, USA. (Fact Sheet, 0.514). Available at: http:// www.ext.colostate.edu/pubs/crops/00514.pdf [Accessed Sept. 22, 2015]

Boesch, D.F.; Brinsfield, R.B.; Magnien, R.E. 2001. Chesapeake Bay eutrophication: scientific understanding, ecosystem restoration, and challenges for agriculture. Journal of Environmental Quality 30: 303-320.

Bonvin, C.; Etter, B.; Udert, K.M.; Frossard, E.; Nanzer, S.; Tamburini, F; Oberson, A. 2015. Plant uptake of phosphorus and nitrogen recycled from synthetic source-separated urine. Ambio 44: 217-227.

Cox, F.R.; Kamprath, E.J.; McCollum, R.E. 1981. A descriptive model of soil test nutrient levels following fertilization. Soil Science Society of America 45: 529-532.

Cruz, P.C.; Banayo, N.P.; Marundan, S.R.; Magnaye, A.M. 2012. Bio-inoculant and foliar fertilizer in combination with soilapplied fertilizer on the yield of lowland rice. Philippine Journal of Crop Science 37: 85-94.

Dai, Z.; Du, J.; Zhang, X.; Su, N.; Li, J. 2011. Variation of riverine material loads and environmental consequences on the Changjiang (Yangtze) estuary in recent decades (1955-2008). Environmental Science \& Technology 45: 223-227.

Dale, V.H.; Wright, D.; Kling, C.L.; Boynton, W.; Meyer, J.L.; Mankin, K.; Sanders, J.; Opaluch, J.; Conley, D.J.; Stallworth, H.; Crumpton, W.; Paerl, H.; Armitage, T.; Reckhow, K.; David, M.; Gilbert, D.; Sharpley, A.N.; Wangsness, D.; Howarth, R.W.; Simpson, T.W.; Bianchi, T.; Blumberg, A.; Lowrance, R.; Snyder, C.S. 2010. Hypoxia in the northern Gulf of Mexico. Springer Science, New York, NY, USA. (Springer Series on Environmental Management).

Daloğlu, I.; Cho, K.H.; Scavia, D. 2012. Evaluating causes of trends in long-term dissolved reactive phosphorus loads to Lake Erie. Environmental Science \& Technology 46: 10660-10666.

Dampney, P.M.R.; Lord, E.I.; Chambers, B.J. 2000. Development of advice for farmers and advisors. Soil Use and Management 16: $162-166$.

Djodjic, F.; Ulen, B.; Bergstrom, L. 2000. Temporal and spatial variations of phosphorus losses and drainage in a structured clay soil. Water Research 34: 1687-1695. 
Dubrovsky, N.M.; Burow, K.R.; Clark, G.M.; Gronberg, J.M.; Hamilton, P.A.; Hitt, K.J.; Mueller, D.K.; Munn, M.D.; Nolan, B.T.; Puckett, L.J.; Rupert, M.G.; Short, T.M.; Spahr, N.E.; Sprague, L.A.; Wilber, W.G. 2010. The Quality of our Nation's Waters-Nutrients in the Nation's Streams and Groundwater, 1992-2004. U.S. Geological Survey, Washington, DC, USA. (Circular, 1350). Available at: http:// water.usgs.gov/nawqa/nutrients/pubs/circ1350 [Accessed Sept. 22, 2015]

Edwards, D.R.; Daniel, T.C. 1993. Drying interval effects on runoff from fescue plots receiving swine manure. Transactions of the American Society of Agricultural and Biological Engineers. 36: 1673-1678.

Gburek, W.J.; Sharpley, A.N. 1998. Hydrologic controls on phosphorus loss from upland agricultural watersheds. Journal of Environmental Quality 27: 267-277.

Harmel, R.D.; Cooper, R.J.; Slade, R.M.; Haney, R.L.; Arnold, J.G. 2006. Cumulative uncertainty in measured streamflow and water quality data for small watersheds. Transactions of the American Society of Agricultural and Biological Engineers 49: 689-701.

Haygarth, P.M.; Jarvie, H.P.; Powers, S.M.; Sharpley, A.N.; Elser, J.J.; Shen, J.; Peterson, H.M. Chan, N.I.; Howden, N.J.K.; Burt,T.; Worrall, F.; Zhang, F.; Liu, X. 2014. Sustainable phosphorus management and the need for a long-term perspective: The legacy hypothesis. Environmental Science \& Technology 48: 8417-8419.

Heathwaite, A.L.; Dils, R.M. 2000. Characterising phosphorus loss in surface and subsurface hydrological pathways. Science of The Total Environment 251: 523-538.

Hilton, J.; O'Hare, M.; Bowes, M.J.; Jones, J.I. 2006. How green is my river? A new paradigm of eutrophication in rivers. Science of The Total Environment 365: 66-83.

Food and Agriculture Organization [FAO]. 2015. World water resources by country. Aquastat Programme of FAO's Land and Water Development Division. Water Reports 23. Available at:ftp://ftp.fao.org/docrep/fao/005/y4473E/y4473E00.pdf [Accessed Sept. 22, 2015]

Instituto Brasileiro de Geografia e Estatística [IBGE]. 2014. Available at: http://www.sidra.ibge.gov.br/bda/tabela/ listabl.asp? $\mathrm{z}=\mathrm{t} \& \mathrm{c}=73 \quad$ [Accessed Sept. 22, 2015] (in Portuguese).

International Fertilizer Association [IFA]. 2009. The Global " $4 \mathrm{R}$ " nutrient stewardship framework: developing fertilizer best management practices for delivering economic, social and environmental benefits. IFA, Paris, France. Available at: https://www.ipni.net/ipniweb/portal/4r.nsf/0/BAB4157B4888 71A385257DF100739D94/\$FILE/The\%20Global\%204R\%20 Nutrient\%20Stewardship\%20Framework.pdf [Accessed Sept. $22,2015]$

International Plant Nutrition Institute [IPNI]. 2014. 4R Nutrient stewardship portal. Available at: http://www.ipni.net/4R [Accessed Sept. 22, 2015]

Jarvie H.P.; Sharpley, A.N.; Withers, P.J.; Scott, J.T.; Haggard, B.E.; Neal, C. 2013. Phosphorus mitigation to control river eutrophication: murky waters, inconvenient truths and 'PostNormal' science. Journal of Environmental Quality 42: 295304.
Jarvie, H.P.; Sharpley, A.N.; Brahana, V.; Simmons, T.; Price, A.; Neal, C.; Lawlor, A.J.; Sleep, D.; Thacker, S.; Haggard, B.E. 2014. Phosphorus retention and remobilization along hydrological pathways in karst terrain. Environmental Science \& Technology 48: 4860-4868.

Kleinman, P.J.A.; Sharpley, A.N.; Withers, P.J.A.; Bergström, L.; Johnson, L.; Doody, D.G. 2015. From sacred cows to sacrificial lambs: implementing agricultural phosphorus science and management to combat eutrophication. Ambio 44: 297-310.

Li, H.; Liu, J.; Li, G.; Shen, J.; Bergström, L.; Zhang, F. 2015. Past, present and future use of phosphorus in Chinese agriculture and its influence on phosphorus losses. Ambio 44: 274-285.

Meals, D.W.; Dressing, S.A.; Davenport, T.E. 2010. Lag time in water quality response to best management practices: Review. Journal of Environmental Quality 39: 85-96.

Michalak, A.M.; Anderson, E.J.; Beletsky, D.; Boland, S.; Bosch, N.S.; Bridgeman, T.B.; Chaffin, J.D.; Cho, K.; Confesor, R.; Daloğlu, I.; DePinto, J.V.; Evans, M.A.; Fahnenstiel, G.L.; He, L.; Ho, J.C.; Jenkins, L.; Johengen, T.H.; Kuo, K.C.; LaPorte, E.; Liu, X.; McWilliams, M.R.; Moore, M.R.; Posselt, D.J.; Richards, R.P.; Scavia, D.; Steiner, A.L.; Verhamme, E.; Wright, D.M.; Zagorski, M.A. 2013. Record-setting algal bloom in Lake Erie caused by agricultural and meteorological trends consistent with expected future conditions. Proceedings of the National Academy of Sciences 110: 6448-6452.

Mueller, D.H.; Wendt, R.C.; Daniel, T.C. 1984. Phosphorus losses as affected by tillage and manure application. Soil Science Society of America 48: 901-905.

National Research Council. 2008. Nutrient control actions for improving water quality in the Mississippi River Basin and Northern Gulf of Mexico. Committee on the Mississippi River and the Clean Water Act: Scientific, Modeling and Technical Aspects of Nutrient Pollutant Load Allocation and Implementation. National Research Council, Washington, DC, USA. Available at: http://www.nap.edu/catalog/12544.html [Accessed Sept. 22, 2015]

Novotny, V.; Wang, X.; Englande, A.J.; Bedoya, D.; Promakasikorn, L.; Tirado, R. 2010. Comparative assessment of pollution by the use of industrial agricultural fertilizers in four rapidly developing Asian countries. Environment, Development and Sustainability 12: 491-509.

Schoumans, O.F.; Bouraoui, F.; Kabbe, C.; Oenema, O.; van Dijk, K.C. 2015. Phosphorus management in Europe in a changing world. Ambio 44: 180-192.

Sharpley, A.N. 1997. Rainfall frequency and nitrogen and phosphorus in runoff from soil amended with poultry litter. Journal of Environmental Quality 26: 1127-1132.

Sharpley, A.N.; Herron, S.; Daniel, T. 2007. Overcoming the challenges of phosphorus-based management in poultry farming. Journal of Soil and Water Conservation 62: 375-389.

Sharpley, A.N.; Richards, R.P.; Herron, S.; Baker, D.B. 2012. Can production and environmental goals coexist in phosphorusbased farm management? Journal of Soil and Water Conservation 67: 149-193.

Sharpley, A.; Jarvie, H.P.; Buda, A.; May, L.; Spears, B.; Kleinman, P. 2013. Phosphorus legacy: Overcoming the effects of past management practices to mitigate future water quality impairment. Journal of Environmental Quality 42: 1308-1326. 
Shigaki, F.; Sharpley, A.N. 2011. Phosphorus source and soil properties effects on phosphorus availability. Soil Science 176: 502-507.

Shigaki, F.; Sharpley, A.N.; Prochnow, L.I. 2006. Sourcerelated transport of phosphorus in surface runoff. Journal of Environmental Quality 35: 2229-2235.

Shulte, R.P.O.; Melland, A.R.; Fenton, O.; Herlhy, M.; Richards, K.; Jordan, P. 2010. Modelling soil phosphorus decline: Expectations of Water Framework Directive policies. Environmental Science \& Policy 13: 472-484.

Sims, J.T.; Kleinman, P.J.A. 2005. Managing agricultural phosphorus for environmental protection. p. 1021-1068. In: Sims, J.T.; Sharpley, A.N., eds. Phosphorus: agriculture and the environment. American Society of Agronomy, Madison, WI, USA.

Smith, D.R.; King, K.W.; Williams, M.R. 2015. What is causing the harmful algal blooms in Lake Erie? Journal of Soil and Water Conservation 70: 27A-29A.

Stewart, W.M.; Gordon, W.B. 2008. Fertilizing for Irrigated Corn: Guide to Best Management Practices. International Plant Nutrition Institute, Peacht ree Corners, GA, USA. Available at: http://www.ipni.net/ipniweb/portal.nsf/0/9bbc50427c6469ae8 52574f200162796/\$FILE/ATT4QHV2/Irrigated_\%20Corn.pdf [Accessed Sept. 22, 2015]

Stutter, M.I. 2015. The composition, leaching and sorption behavior of some alternative sources of phosphorus for soils. Ambio 44: 207-216.

Sun, B.; Zhang, L.; Yang, L.; Zhang, F.; Norse, D.; Zhu, Z. 2012. Agricultural non-point source pollution in China: causes and mitigation measures. Ambio 41: 370-379.
United States Department of Agriculture [USDA]. 2013. Fertilizer use and prices. Economic Research Service, Washington, DC, USA. Available at: http://www.ers.usda.gov/data-products/ fertilizer-use-and-price.aspx\# [Accessed Sept. 22, 2015]

United States Department of Agriculture [USDA]. 2015a. Global Agricultural Information Network: Grain and Feed Update. Foreign Agricultural Service, Washington, DC, USA. (GAIN Report BR0958).

United States Department of Agriculture [USDA]. Global Agricultural Information Network: Oilseeds and Products Update. Foreign Agricultural Service, Washington, DC, USA. (GAIN Report BR0957).

United States Department of Agriculture [USDA]. 2015c. World Agricultural Production. Foreign Agricultural Service, Washington, DC, USA. Available at: http://apps.fas.usda.gov/ psdonline/circulars/production.pdf [Accessed Sept. 22, 2015]

United States Department of Agriculture [USDA]. 2009. Mississippi River Basin Initiative. Natural Resources Conservation Service, Washington, DC, USA. Available at: http://www.nrcs.usda.gov/wps/portal/nrcs/detailfull/national/ home/?cid = stelprdb1048200 [Accessed Sept. 22, 2015]

Westerman, P.W.; Donnely, T.L.; Overcash, M.R. 1983. Erosion of soil and poultry manure: a laboratory study. Transactions of the ASAE 26: 1070-1078, 1084.

Withers, P.J.A.; Jarvie, H.P. 2008. Delivery and cycling of phosphorus in UK rivers: Implications for catchment management. Science of the Total Environment 400: 379-395.

Yara. 2014. Liquid fertilizer solutions. Available at: http://yara. co.uk/crop-nutrition/knowledge/yara-chafer-literature/liquidfertilizer-brochure/ [Accessed Sept. 22, 2015] 